states should have walls seems to derive both from Scott's focus on Mesopotamia and his projection of a proto-Modernist dystopian political monolith that must keep its population from fleeing, while also protecting its assets from predatory state and non-state actors-a sort of Mad Max: Fury Road meets 1984. The prominent examples, from Anyang to Teotihuacan, of early complex polities without walls never bubble to the surface of Scott's relentlessly simplifying narrative. Likewise, archaeological work of the last several decades demonstrating the variety of political forms and modes of authority that fall under the rubric 'early complex polities' is ignored. In Scott's vaguely Marxian telling, 'states' are invariably parasiticthe bringers of nothing but subjugation, pestilence and war. They are fragile simplification machines, archaic versions of the reified high Modern state he critiques in his earlier writings. It is not surprising, then, that he focuses on Ur III or the Qin dynasty, selecting two of the most precociously totalitarian regimes of the ancient world, the latter famously short-lived. Of course, if Scott had chosen not to ignore the 2000 years of early complex polities before the Qin empire, his simplifying narrative would have become untenable. The beginning of a dramatic increase in the scale of societies and urban agglomerations at the end of the third millennium $\mathrm{BC}$ was not due to the simplification of agricultural practices to millet production-millet had been domesticated millennia before-but rather corresponds with a diversified complex of crops including rice, wheat and soybeans and livestock including grasseating domesticates introduced from the Eurasian Steppe. Diversification, not simplification, characterizes the first great watershed of social complexity in China.

Taxation in many early complex polities, likewise, does not consist of extraction in kind, but rather in labour. Thus, the argument that lentils and tubers cannot be the basis of state subsistence economies problematically assumes that rulers cannot simply demand a certain amount of agricultural service on their lands-a perfectly legible and rational way of extracting surplus. The truth is that ancient complex polities everywhere relied on a spectrum of food resources and a variety of fiscal mechanisms - in Mesopotamia and elsewhere-and Scott's exclusive focus on grain has more to do with his teleology of the simplifying, mono-cropping Modernist state than it does with ancient history.

In the end, and despite the apparent progressiveness of his grand narrative, what bothers me most about Against the Grain, aside from its cherry-picking abuse of archaeological data, is that in its haste to critique 'civilization' and pillory his old enemy 'the state', Scott tramples on the richness of history, denying, with his own simplifications, the diversity of past political forms and, by extension, possible futures. If all governance is domination and domestication an unmitigated evil, what are we supposed to do? With no chance of the world's 7.6 billion humans instantly dropping 'off the grid' short of some global calamity, perhaps a better use of the past than paving it over with tendentious meta-narrative would be to take it seriously, learn its lessons, and let the richness of lost human worlds teach us new lessons for the future.

Rod Campbell
Institute for the Study of the Ancient World
New York University
15 E. 84th Street
New York, NY 10028
USA
Email: rbc2@nyu.edu

\title{
An Archaeobotanical Perspective on the Relationship between Grain Crops, Non-Grain Crops and States
}

\author{
Jade d'Alpoim Guedes
}

Asking the public to question the assumption that our current systems of governance and food production represent the apex of an evolutionary trajectory is timely and well warranted.

CAJ 29:4, 694-696 $\quad$ C 2019 McDonald Institute for Archaeological Research. This is an Open Access article, distributed under the terms of the Creative Commons Attribution licence (http://creativecommons.org/licenses/by/4.0/), which permits unrestricted re-use, distribution, and reproduction in any medium, provided the original work is properly cited.

doi:10.1017/S0959774319000350
Scott has sided with the 'Highway-to-hell' (Antrosio 2011) view of the origins of farming, popularized by Diamond (1987). He differs in that he situates the turning point to hell not with the origins of farming itself, but rather with the origins of the state. Drawing on more than half a century of research in anthropology and archaeology, he argues that early states are 'ecologically and politically and prone to collapse and fragmentation' (p. 27). For Scott, 'grains make states' and the state's reliance on legible and easily taxable cereals reduces the scope of a society's food webs setting up the perfect storm of food 
insecurity when climate change or crop disease struck. Although the concentration of food and population in 'multi-species resettlement camps' created the conditions for the origins of the states, they were also plagued by high levels of social inequality and epidemic disease. The subsistence basis of these states rested on a 'slender and fragile genetic foundation: a handful of crops, a few species of livestock and a radically simplified landscape that had to be constantly defended against a reconquest by excluded nature' (p. 112). On the other hand, we have what Scott calls the 'barbarian zone', characterized by the type of production illegible to states: 'hunting, slash-and-burn cultivation, shellfish collection, foraging, pastoralism, roots and tubers, and few if any standing grain crops. A ... zone of physical mobility, mixed and shifting subsistence strategies' (p. 33).

Scott (p. 133) is right to argue that the above-ground, highly visible nature and more uniform ripening of cereals makes them easier to tax, collect and be transported than other foods such as tubers or tree crops. I question, however, the all-important role that cereals played in states, arguing that farmers within state-level societies around the world often engage in much more complex patterns of subsistence that bridge the divide between wild and cultivated, but also between grains and other crops. Likewise, I challenge the idea that individuals who reside in what Scott calls the barbarian zone employ 'few if any standing grain crops'.

Archaeobotanists have tended to focus on the domestication and identification of cereal grains (or caryopses). The hard caryopsis is often charred through the very process of grain processing itself that sometimes involves toasting the grain, and the recognizable structure of the grain caryopsis (a hard and dry type of fruit) makes it easily identifiable in the archaeological record. Tubers are often mashed and roasted and are less likely to be preserved in the archaeological record, and identifying tuberous material or parenchyma in the macrobotanical record (or the record visible by the naked eye) is extremely challenging. The methods used to quantify the presence of tubers in the archaeological record are often not comparable to those used for grain caryopses. In many regions of the world such as east Asia, archaeobotanists employ counts and not weights to quantify grains; however, counts cannot reflect the importance of tuber-like material. More often than not, particularly when parenchyma cannot be identified, remains that may belong to tubers are simply not reported. Where microbotanical analyses of starch grains and phytoliths have been used to identify the presence of geophytes and root crops, these show up in high abundance on tools (e.g. Rumold \& Aldenderfer 2016). For the Maya, tuber crops such as manioc (Manihot esculenta) and rainforest foods such as breadnut (Brosimum alicastrum) (e.g. Cagnato \& Ponce 2017; Ford \& Nigh 2015; Sheets et al. 2011) have been demonstrated not to have just been famine foods, but rather to have served as important resources both through periods of state formation and beyond. In the Maya region, Wright
(1997) has used stable isotopic evidence from several sites to argue that there is no clear signature for an increase in maize consumption across the area throughout the period of state formation.

Part of the reason that Scott argues that tubers may not have played an important role for early states relates to his assertion that they are difficult to store. However, ethnographic and archaeological evidence demonstrates that, in groups for whom tubers were important, a range of storage practices existed. For instance, manioc can be stored in chultunes for as long as 16 weeks (Miksicek et al. 1991), and as Cagnato and Ponce (2017) point out, the fact that this crop can be cultivated year-round itself removes somewhat the need for storage. In the Andes, potatoes and oca are freeze-dried to produce chuno and calla respectively and require only sunlight and freezing nights (Hastorf 2016, 96). Hastorf and Johannessen (1993) have argued that archaeological evidence for freeze-drying these resources is present in the characteristic alteration of starch granules from these species found in archaeological sites. The under-emphasizing of these resources in the diet is at least partially the result of the biases of the work of early chroniclers who focused on grain crops because of own cultural familiarity with these crops.

I do not take quite as grim a view of farmer know-how and their ability to hedge bets even when living under the state itself. Scott writes that 'Farmers, especially fixed-field cereal-grain farmers are largely confined to a single food web, and their routines are geared to its particular tempo' (p. 90). However, there are a great many farmers who practice intensive systems of cultivation and who do not live 'in isolation from larger networks of economic exchange or political organization' (Netting 1993, 15). Netting's smallholder's (1993) provide one such example of the latter. While a grain crop might play a role in smallholder farming, it is often only one of many seasonal rotations in which farmer's practical knowledge (or 'metis': Scott 1998) allows them to maintain both diverse and highly productive farming systems. This is particularly the case in east and southeast Asia, where rice paddies contain extremely biodiverse food webs which include, fish, ducks, insects and wild plants (Xie et al. 2011). Archaeological evidence demonstrates that systems based on diversity were present as early as the development of some of the earliest states in Asia (Bray 1994; d'Alpoim Guedes et al. 2019). Today, on the Chengdu plain, summer rice is but a single crop rotation that is followed by a myriad of vegetables, oil crops and greens in the winter time, items that are prized more than the grain itself. Their diverse farming systems have survived the different states, the periods of 'darkness' between them, and more recently collectivization and the green revolution.

I argue that divide between systems of cultivation inside and outside states is not quite as clear-cut as Scott suggests. Grains can play an important role in the diet and cultivation systems in areas outside the state, contrary to Scott's assertion that there were 'few if any standing grain crops'. My own work on the Tibetan plateau has demonstrated that both prior to and throughout the 
formation of early states in the region (d'Alpoim Guedes 2015; d'Alpoim Guedes et al. 2013; 2015; 2016), standing crops of wheat and barley rapidly moved to form a major component of the diet following their introduction during the second millennium $\mathrm{BC}$ and became important commodities that connected the economies of those engaged in full-time farming (shingpas), part-time pastoralism or vertical transhumance (samadrok) and full-time nomadic pastoralists (drogpas). This was true even of areas which were outside of the realm of any state control, such as at Ashaonao site in the Jiuzhaigou National park (d'Alpoim Guedes et al. 2015). In the Philippines, recent work by Acabado (2018) uses a wide suite of evidence to suggest that, rather being pushed to the margins or regions where only slash-and-burn or foraging were employed, Ifugao farmers' adoption of intensive systems of wet rice farming was the very factor that allowed them actively to resist Spanish colonizers.

While the trappings of state-craft can encourage an ecological highway-to-hell, it does not have to be this way (nor has it always been). The farmers within these systems often find ways to ensure the biodiversity of their farming systems beyond grain alone, while those outside of state control often incorporate grains into their diet.

Jade d'Alpoim Guedes
Department of Anthropology
Scripps Institution of Oceanography
University of California, San Diego
9500 Gillman Drive
La Jolla, CA, 92037
USA
Email: jguedes@ucsd.edu

\section{References}

Acabado, S., 2018. Zones of refuge: resisting conquest in the northern Philippine highlands through environmental practice. Journal of Anthropological Archaeology 52, 180-95.

Antrosio, J., 2011. Many ways of gathering and hunting. Living Anthropologically. https://www.livinganthropologically. com/archaeology/gathering-and-hunting/

Bray, F., 1994. The Rice Economies: Technology and development in Asian societies. Los Angeles (CA): University of California Press.

Cagnato, C. \& J.M. Ponce, 2017. Ancient Maya manioc (Manihot esculenta Crantz) consumption: starch grain evidence from late to terminal classic (8th-9th century CE) occupation at La Corona, northwestern Petén, Guatemala. Journal of Archaeological Science: Reports 16, 276-86.

d'Alpoim Guedes, J., 2015. Rethinking the spread of agriculture to the Tibetan plateau. Holocene 25(9), 1498-1510.

d'Alpoim Guedes, J., S. Hanson, C. Higham, T. Higham \& T. Lechtcharnrit, 2019. The wet and the dry, the wild and the cultivated: subsistence and risk management in ancient Central Thailand Archaeological and Anthropological Sciences. https://doi.org/10.1007/ s12520-019-00794-8

d'Alpoim Guedes, J.A., H. Lu, A.M. Hein \& A.H. Schmidt, 2015. Early evidence for the use of wheat and barley as staple crops on the margins of the Tibetan plateau. Proceedings of the National Academy of Sciences 112(18), 5625-30.

d'Alpoim Guedes, J., H. Lu, Y. Li, R.N. Spengler, X. Wu \& M. Aldenderfer, 2013. Moving agriculture onto the Tibetan plateau: the archaeobotanical evidence. Archaeological and Anthropological Sciences 6, 255-69.

d'Alpoim Guedes, J., S.W. Manning \& R.K. Bocinsky, 2016. A 5,500-year model of changing crop niches on the Tibetan plateau. Current Anthropology 57(4), 517-22.

Diamond, J., 1987. Worst mistake in the history of the human race. Discover Magazine (May), 95-8.

Ford, A. \& R. Nigh, 2015. The Maya Forest Garden: Eight millennia of sustainable cultivation of the tropical woodlands. London/New York: Routledge.

Hastorf, C.A., 2016. The Social Archaeology of Food: Thinking about eating from prehistory to the present. Cambridge: Cambridge University Press.

Hastorf, C.A. \& S. Johannessen, 1993. Pre-Hispanic political change and the role of maize in the central Andes of Peru. American Anthropologist 95(1), 115-38.

Miksicek, C.H., E.S. Wing \& S.J. Scudder, 1991. The ecology and economy of Cuello, in Cuello: An early Maya community in Belize, ed. N. Hammond. Cambridge (MA): Harvard University Press, 70-84.

Netting, R.C., 1993. Smallholders, Householders: Farm families and the ecology of intensive, sustainable agriculture. Stanford (CA): Stanford University Press.

Rumold, C.U. \& M.S. Aldenderfer, 2016. Late ArchaicEarly Formative period microbotanical evidence for potato at Jiskairumoko in the Titicaca Basin of southern Peru. Proceedings of the National Academy of Sciences 113(48), 13672.

Scott, J.C., 1998. Seeing Like a State: How certain schemes to improve the human condition have failed. New Haven (CT): Yale University Press.

Sheets, P., C. Dixon, M. Guerra \& A. Blanford, 2011. Manioc cultivation at Ceren, El Salvador: occasional kitchen garden plant or staple crop? Ancient Mesoamerica 22(1), 1-11.

Wright, L.E., 1997. Ecology or society: paleodiet and the colapse of the Pasión Maya Lowlands, in The Bones of the Maya: Studies of ancient skeletons, edited by S.L. Whittington, D.M. Reed \& L. E. Wright. Tuscaloosa (AL): University of Alabama Press, 181-95.

Xie, J. L. Hu, J. Tang, et al., 2011. Ecological mechanisms underlying the sustainability of the agricultural heritage rice-fish coculture system. Proceedings of the National Academy of Sciences 108(50), E1381-E1387. 